\title{
Formalin Test using Extract of Red Chrysanthemum Flower as Indicator into White Tofu and Tempeh (in Ende Traditional Market)
}

\author{
Uji Formalin Menggunakan Ekstrak Bunga Krisan Merah sebagai Indikator \\ Tahu Putih dan Tempe (di Pasar Tradisional Ende)
}

\author{
Melania Priska ${ }^{\mathrm{a}, 1, *}$, Veronika P. S. M. Wae ${ }^{\mathrm{a}, 2}$, Ludovicus Carvallo ${ }^{\mathrm{b}, 3}$, Natalia Peni ${ }^{\mathrm{b}, 4}$ \\ ${ }^{\text {a }}$ Program Studi Pendidikan Biologi, Universitas Flores, Jl. Sam Ratulangi No. XX, Kel. Paupire, Ende - Flores - NTT, Indonesia \\ ${ }^{\mathrm{b}}$ Program Studi Pendidikan Matematika, Universitas Flores, Jl. Sam Ratulangi No. XX, Kel. Paupire, Ende - Flores - NTT, Indonesia \\ ${ }^{1}$ pika87cutes@gmail.com*; ${ }^{2}$ veronikapsmwae88@gmail.com; ${ }^{3}$ ludovicuscarvallo@gmail.com; ${ }^{4}$ nataliapeni27@gmail.com \\ * corresponding author
}

\section{ARTICLE INFO}

Article history

Received April 29, 2020

Revised June 11, 2020

Accepted June 18, 2020

Keywords

White Tofu

Tempeh

Formalin

Red Chrysanthemum Flower

\section{ABSTRACT}

Formalin in food is very disturbing for the people. Lack of public knowledge about the harmful effects of formaldehyde, the difficulty of distinguishing food that contains and does not contain formaldehyde, lack of knowledge in simply identifying formaldehyde in food is the cause of the increasingly widespread use of formaldehyde in food. This study aims to examine the presence of formalin in white tofu and tempeh circulating in the traditional markets of Ende district by using red chrysanthemum flower extract as a natural indicator. This type of research is an experimental study with descriptive qualitative data analysis techniques. Sampling is done using random sampling techniques. The samples used came from the 3 largest traditional markets in Ende district, namely Wolowona Market, Senggol Market, and Ende Market. From the test results using red chrysanthemum extract showed that the white tofu and tempeh circulating in some traditional markets of Ende district were negative or did not contain formaldehyde. Based on the results of these tests it can be concluded that the red chrysanthemum flower extract can be used as a natural indicator to determine the presence of formalin in food, especially in white tofu and tempeh.

This is an open access article under the CC-BY-SA license.

\section{Pendahuluan}

Pembusukan pada berbagai jenis bahan makanan disebabkan karena adanya kerusakan fisiologis, mekanis, mikrobiologis, fisik, kimia, dan biologis. Kerusakan pada bahan makanan umumnya disebabkan karena lamanya waktu penyimpanan dari bahan makanan itu sendiri yang relatif singkat, sehingga dari kerusakan tersebut timbul perubahan atau penyimpangan dari keadaan semula yang tidak dapat diterima oleh konsumen. Adanya penyimpangan dari keadaan semula baik itu tekstur, aroma, $\mathrm{pH}$, warna, cita rasa disebabkan oleh beberapa faktor, yaitu pertumbuhan dan aktifitas mikroba, aktifitas enzim dalam bahan makanan, suhu, kadar air, udara, penyinaran, dan lama penyimpanan. Faktor-faktor tersebut dapat menyebabkan berubahnya komposisi bahan makanan [1].

Tahu tempe merupakan salah satu jenis olahan bahan makanan yang berasal dari hasil fermentasi kacang kedelai dan bernilai protein tinggi. Rata-rata masyarakat mengonsumsi tahu sebanyak 2,24 $\mathrm{g} /$ kapita/hari dan tempe 2,30 g/kapita/hari [2]. Untuk mendukung pemasaran tahu dan tempe, berdasarkan data hasil Survei Sosial Ekonomi Nasional (SUSENAS) yang dikeluarkan oleh Badan Pusat Statistik (BPS) pada Maret 2018, Pemerintah Provinsi Nusa Tenggara Timur (NTT) telah 
menyediakan komoditas tahu dan tempe untuk setiap bulannya baik di wilayah perkotaan maupun pedesaan. Rata-rata jumlah pengeluaran komoditas tahu yaitu sebesar $0,548 \mathrm{~kg} / \mathrm{kapita} / \mathrm{bulan}$ untuk wilayah perkotaan dan $0,167 \mathrm{~kg} / \mathrm{kapita} / \mathrm{bulan}$ untuk wilayah pedesaan, sedangkan pengeluaran jenis komoditas tempe di wilayah perkotaan rata-rata jumlahnya sebesar $0,440 \mathrm{~kg} / \mathrm{kapita} / \mathrm{bulan}$ dan di wilayah pedesaan sebesar $0,125 \mathrm{~kg} / \mathrm{kapita} / \mathrm{bulan}$ [3].

Tingginya minat masyarakat terhadap kedua jenis olahan kacang kedelai ini disebabkan karena harganya yang dapat dijangkau oleh berbagai kalangan masyarakat, bergizi, berkualitas, dan juga aman untuk dikonsumsi. Namun pada kenyataannya dalam proses pengolahan kacang kedelai menjadi tahu tempe, secara umum belum terlalu memperhatikan dari segi kebersihan. Proses pengolahan yang kurang higienis ini dapat menjadikan tahu tempe tidak bertahan lama, mudah rusak, berlendir, berbau sengit, serta berasa asam [4].

Tahu tempe diketahui memiliki daya simpan yang cukup singkat dan cepat busuk. Hal ini dikarenakan komposisi dari tahu dan tempe yang kaya akan protein dan air sehingga cocok dijadikan sebagai tempat hidup dan berkembangnya mikroba. Berdasarkan hasil wawancara dengan para pedagang tahu tempe di 3 (tiga) pasar tradisional terbesar di kabupaten Ende, rata-rata lama penyimpanan pada suhu ruang di daerah tropis $\left(24-25^{\circ} \mathrm{C}\right)$ untuk tahu putih adalah sekitar $1-3$ hari saja walaupun diganti airnya setiap hari, sedangkan untuk tempe adalah 3 hari setelah penyimpanan. Pada suhu rendah $\left(15^{\circ} \mathrm{C}\right)$, kesegaran tahu dan tempe hanya dapat bertahan selama 1-2 hari saja [5].

Minimnya waktu penyimpanan tahu putih dan tempe dikarenakan oleh adanya kerusakan mikrobiologis yang disebabkan oleh bakteri kontaminan yang bersifat tahan terhadap panas. Semakin tinggi suhu penyimpanan, maka proses kerusakan mikrobiologis pada tahu tempe akan semakin cepat terjadi. Hal ini dikarenakan aktivitas enzim dari enzim-enzim yang dihasilkan oleh golongan bakteri tertentu dalam tahu dan tempe yang tahan terhadap panas akan semakin mempercepat reaksi enzimatisnya [6]. Untuk mempertahankan kualitas tahu tempe yang dijual di pasaran dan juga dapat disimpan dalam jangka waktu yang lama, sering kali para pedagang, produsen atau industri menambahkan bahan pengawet sintetis berbahaya seperti formalin dan boraks [7].

Formalin merupakan senyawa kimia tak berwarna yang biasanya digunakan sebagai bahan desinfektan. Penggunaan formalin saat ini dalam dunia pangan sangat disesalkan, hal ini dikarenakan sifat toksik dari formalin itu sendiri yang berbahaya bagi kesehatan manusia, dimana dapat menimbulkan kerusakan organ tubuh hingga dapat menimbulkan kematian [8]. Efek mengonsumsi formalin dalam jangka pendek dapat menyebabkan iritasi, gatal, dan penglihatan kabur jika terkena mata; kerusakan hati, jantung, otak, limpa, ginjal, dan lain-lain jika tertelan; iritasi pada hidung, tenggorokan, batuk, diare, dan gangguan pernafasan jika terhirup [9]. Sedangkan efek negatif jangka panjang yang ditimbulkan jika terhirup adalah gangguan menstruasi dan kemandulan pada perempuan; hingga kanker otak, dan kematian. Dari berbagai efek samping tersebut, dampak formalin bagi kesehatan manusia dapat bersifat akut dan kronik [10].

Penggunaan formalin pada bahan pangan telah dilarang oleh pemerintah Indonesia, dengan dikeluarkannya Peraturan Pemerintah Republik Indonesia Nomor 28 Tahun 2004 dan Peraturan Menteri Kesehatan RI No. 033 tahun 2012 [11]. Namun adanya peraturan tersebut tidak membuat penggunaan formalin pada bahan pangan semakin berkurang, malahan semakin merajalela. Hal tersebut sangat meresahkan masyarakat. Hal ini dikarenakan kurangnya pengetahuan masyarakat akan efek samping berbahaya dari formalin [12]. Selain itu juga, masyarakat tidak dapat membedakan bahan pangan yang mengandung formalin dan yang tidak mengandung formalin. Masyarakat juga tidak memiliki pengetahuan akan bagaimana caranya mengidentifikasi formalin secara sederhana pada bahan makanan dengan menggunakan bahan-bahan seadanya yang dapat masyarakat temukan di sekitar lingkungan tempat tinggal. Bahan-bahan seadanya yang ditemukan di sekitar lingkungan tempat tinggal yang dapat digunakan untuk mengidentifikasi formalin biasanya berupa jenis tanaman baik itu bunga, buah, dan sayuran. Adapun jenis tanaman yang sering dimanfaatkan untuk mengidentifikasi formalin dalam bahan pangan antara lain adalah kelopak bunga kembang sepatu, kelopak bunga rosela, umbi ubi jalar ungu, kulit buah naga, stroberi, dan anggur $[13,14,15]$.

Walaupun penelitian uji formalin bukanlah penelitian baru dan telah banyak dilakukan, namun dengan adanya penelitian ini diharapkan masyarakat kabupaten Ende dapat memanfaatkan berbagai bahan alam yang ada, seperti bunga krisan merah yang belum pernah digunakan sebagai indikator 
alami untuk menguji keberadaan formalin dalam tahu putih dan tempe yang beredar di pasar tradisional kabupaten Ende. Penggunaan ekstrak pada bunga krisan merah diduga dapat menguji keberadaan formalin dalam tahu putih dan tempe. Hal ini dikarenakan dalam bunga krisan terkandung pigmen antosianin, yang merupakan golongan senyawa polifenol yang dapat digunakan untuk menguji adanya senyawa kimia seperti formalin [16,17].

\section{Metode}

Jenis penelitian yang dilakukan adalah penelitian eksperimen dengan teknik analisis data secara deskriptif kualitatif, dimana variabel yang diamati adalah perubahan warna hasil reaksi formalin dengan ekstrak bunga krisan merah. Penelitian ini dilaksanakan selama 2 bulan, dari bulan OktoberNovember 2019 bertempat di Laboratorium LOKA Pengawas Obat dan Makanan (POM) Kabupaten Ende. Adapun sumber data yang digunakan adalah sumber data primer yang diperoleh dari hasil observasi, wawancara, dan dokumentasi. Teknik pengambilan sampel pada penelitian ini menggunakan teknik random sampling yaitu sampel dipilih secara acak tanpa memperhatikan strata yang ada dalam populasi itu. Dengan kata lain, setiap elemen atau anggota populasi memiliki kesempatan yang sama untuk terpilih menjadi sampel. Sampel yang digunakan berasal dari 3 pasar tradisional terbesar di kabupaten Ende, yaitu Pasar Wolowona, Pasar Senggol, dan Pasar Ende. Bahan uji yang digunakan untuk melakukan identifikasi keberadaan formalin adalah ekstrak bunga krisan merah. Sampel bahan makanan yang diujikan adalah tahu putih dan tempe.

Uji keberadaan formalin pada tahu putih dan tempe meliputi beberapa tahap pelaksanaan, yaitu diawali dengan uji organoleptik sebanyak 3 sampel tahu putih dan 3 sampel tempe. Pengujian organoleptik dilakukan selama 1 (satu) hari. Setelah melakukan pengujian organoleptik dilanjutkan dengan pembuatan larutan formalin 1\%, pembuatan ekstrak bunga krisan merah, preparasi sampel, pembuatan sediaan tahu putih dan tempe berformalin, identifikasi formalin pada sediaan tahu putih dan tempe berformalin menggunakan ekstrak bunga krisan merah sebagai kontrol positif $(+)$, dan tahapan yang terakhir adalah identifikasi formalin pada sampel tahu putih dan tempe menggunakan ekstrak bunga krisan merah. Pengulangan identifikasi formalin ini dilakukan sebanyak 3 (kali) untuk setiap sampel.

\subsection{Uji Organoleptik Tahu Putih (SNI 01-3142-1998)}

Pengujian organoleptik pada tahu putih dilakukan berdasarkan standar uji SNI 01-3142-1998. Jenis pengujian yang dilakukan berupa uji keadaan, yang terdiri dari: bau, rasa, warna, dan penampakan [18]. Adapun metode pengujian yang digunakan sebagai berikut:

Bau: Sejumlah sampel tahu putih diambil dan diletakkan ke dalam wadah yang bersih dan kering, kemudian dicium sampel tersebut untuk mengetahui baunya. Jika tercium bau khas tahu, maka hasil dinyatakan "normal" dan jika tercium selain bau tersebut, maka hasil dinyatakan "tidak normal”.

Rasa: Sejumlah sampel tahu putih diambil dan diletakkan ke dalam wadah yang bersih dan kering. Sampel tersebut kemudian diambil dan dirasakan dengan indera perasa. Jika rasa khas tahu, maka hasil dinyatakan "normal" dan jika terasa selain rasa tahu tersebut, maka hasil dinyatakan "tidak normal".

Warna: Sejumlah sampel tahu putih diambil dan diletakkan ke dalam wadah yang bersih dan kering. Perhatikan sampel tersebut untuk mengetahui warnanya. Jika tahu berwarna putih normal, maka hasil dinyatakan "putih normal" dan jika warna lain dari putih normal hasil dinyatakan "tidak normal".

Penampakan: Sejumlah sampel tahu putih diambil dan diletakkan ke dalam wadah yang bersih dan kering. Sampel tersebut kemudian diamati untuk mengetahui penampakannya dengan mengusap menggunakan jari tangan. Jika tahu diusap normal tidak berlendir dan diamati tidak berjamur, maka hasil dinyatakan "normal, tidak berlendir dan berjamur" dan jika tahu diusap tidak normal, berlendir, dan berjamur maka disebutkan penampakan yang diamati.

\subsection{Uji Organoleptik Tempe (SNI 3144-2015)}

Pengujian organoleptik pada tempe dilakukan berdasarkan standar uji SNI 3144-2015. Jenis pengujian yang dilakukan berupa uji keadaan, yang terdiri dari: tekstur, warna, dan bau [19]. Adapun metode pengujian yang digunakan sebagai berikut: 
Tekstur: Sejumlah sampel tempe diambil dan diletakkan ke dalam wadah yang bersih dan kering. Kemudian diamati sampel tersebut untuk mengetahui teksturnya dengan menekan menggunakan jari tangan dan dilanjutkan dengan mengiris sampel tersebut dengan menggunakan pisau yang bersih. Apabila tempe yang ditekan dan diiris tetap utuh (tidak mudah rontok), maka hasil dinyatakan "kompak, jika diiris tetap utuh (tidak mudah rontok)". Jika teksturnya ditekan dan diiris tidak kompak, tidak utuh (mudah rontok), maka disebutkan tekstur yang diamati.

Warna: Sejumlah sampel tempe diambil dan diletakkan ke dalam wadah yang bersih dan kering. Perhatikan sampel untuk mengetahui warnanya. Jika warna putih merata, hasil dinyatakan "putih merata pada seluruh permukaan". Jika warna lain dari putih merata, hasil dinyatakan tidak normal.

Bau: Sejumlah sampel tempe diambil dan diletakkan ke dalam wadah yang bersih dan kering. Sampel dicium untuk mengetahui baunya. Jika tercium bau khas tempe tanpa adanya bau amoniak, maka hasil dinyatakan "bau khas tempe tanpa ada bau amoniak". Jika tercium selain bau tersebut, maka hasil dinyatakan "tidak normal".

\subsection{Pembuatan Larutan Formalin $1 \%$}

Sebanyak 2,7 mL formalin 37\% diambil dan dimasukkan ke dalam labu ukur $100 \mathrm{~mL}$. Kemudian diencerkan dengan akuades sampai $100 \mathrm{~mL}$. Kemudian disaring dan ditempatkan dalam wadah tertutup rapat.

\subsection{Pembuatan Ekstrak Bunga}

Setiap mahkota dari bunga krisan merah di cuci bersih, kemudian dikeringkan dengan cara diangin-anginkan. Setelah kering, mahkota bunga tersebut kemudian ditimbang sebanyak $10 \mathrm{~g}$. Sebanyak $10 \mathrm{~g}$ mahkota bunga krisan merah dihaluskan dan dimaserasi dengan akuades sebanyak 50 $\mathrm{mL}$ selama 24 jam.

\subsection{Preparasi Sampel}

Sampel tahu putih dan tempe yang telah diambil secara acak dari ketiga pasar tradisional di kabupaten Ende dikumpulkan dan dicuci bersih. Setelah itu sampel dikeringkan dengan cara diangin-anginkan.

\subsection{Pembuatan Sediaan Tahu Putih dan Tempe Berformalin}

Sampel tahu putih dan tempe ditimbang masing-masing sebanyak $5 \mathrm{~g}$. Tahu dan tempe yang telah ditimbang kemudian direndam masing-masing dalam larutan formalin $1 \%$ selama 2 jam. Selanjutnya masing-masing tahu dan tempe ditumbuk dalam mortar. Setelah ditumbuk, pada masing-masing sediaan tahu dan tempe ditambahkan aquades sebanyak $10 \mathrm{ml}$, kemudian disaring. Filtrat yang diperoleh disimpan dalam botol sampel atau wadah tertutup rapat.

\subsection{Identifikasi Formalin pada Sediaan Tahu Putih dan Tempe Berformalin menggunakan Ekstrak Bunga (Kontrol Positif)}

Filtrat dari sediaan tahu putih dan tempe berformalin diambil masing-masing sebanyak $1 \mathrm{~mL}$ dan dimasukkan ke dalam tabung reaksi. Selanjutnya diambil ekstrak bunga krisan merah masingmasing sebanyak $1 \mathrm{~mL}$ dan dimasukkan ke dalam tabung reaksi yang tersebut. Dikocok dan diamati perubahan warnanya. Jika tidak ada perubahan warna, dilanjutkan dengan pemanasan selama \pm 1 menit dengan suhu $70-80{ }^{\circ} \mathrm{C}$, sambil diamati perubahan warnanya. Hasil yang didapat dijadikan sebagai kontrol positif [20].

\subsection{Identifikasi Formalin pada Sampel Tahu Putih dan Tempe menggunakan Ekstrak Bunga}

Sebanyak $5 \mathrm{~g}$ sampe tahu putih dan tempe dihaluskan, kemudian ditambahkan dengan akuades sebanyak $10 \mathrm{ml}$ pada masing-masing sampel dan direndam selama 2 jam. Setelah itu disaring. Filtrat yang diperoleh kemudian ditambahkan masing-masing dengan $1 \mathrm{~mL}$ ekstrak bunga krisan merah. Dikocok dan diamati perubahan warnanya. Jika tidak ada perubahan warna, sampel dipanaskan selama \pm 1 menit dengan suhu $70-80^{\circ} \mathrm{C}$, sambil diamati perubahan warnanya. Hasil yang didapat, dibandingkan dengan kontrol positif dan dilakukan pengulangan sebanyak 3 (tiga) kali pengulangan. 


\section{Hasil dan Pembahasan}

\subsection{Hasil Uji Organoleptik Tahu Putih dan Tempe}

Uji organoleptik pada sampel tahu putih dengan menggunakan metode SNI 01-3142-1998, dengan jenis pengujian yang dilakukan berupa uji keadaan, yaitu: bau, rasa, warna, dan penampakan/tekstur. Untuk sampel tempe, uji organoleptik dengan menggunakan metode SNI 31442015 dengan jenis pengujian keadaannya, yaitu penampakan/tekstur, warna, dan bau. Hasilnya dapat dilihat pada Tabel 1.

Berdasarkan Tabel 1, diketahui bahwa hasil uji organoleptik pada sampel tahu putih yang beredar di pasar tradisional kota Ende dikatakan memenuhi standar (MS) untuk dapat dijual dan dikonsumsi oleh masyarakat karena negatif mengandung formalin. Hal tersebut dikarenakan hasil yang diperoleh sesuai dengan standar hasil yang ditetapkan dalam SNI 01-3142-1998 dan SNI 3144-2015 untuk tempe.

Tabel 1. Hasil Uji Organoleptik Sampel Tahu Putih dan Tempe yang Beredar di Pasar Tradisional Kabupaten Ende

\begin{tabular}{|c|c|c|c|c|c|}
\hline \multirow{2}{*}{$\begin{array}{c}\text { Kode } \\
\text { Sampel }\end{array}$} & \multicolumn{4}{|c|}{ Hasil Pengujian Organoleptik } & \multirow{2}{*}{$\begin{array}{c}\text { Standar } \\
\text { SNI }\end{array}$} \\
\hline & Penampakan/Tekstur & Warna & Bau & Rasa & \\
\hline ThEJ & $\begin{array}{l}\text { Normal tidak berlendir dan } \\
\text { tidak berjamur }\end{array}$ & Putih normal & Normal & Normal & MS \\
\hline ThK & $\begin{array}{l}\text { Normal tidak berlendir dan } \\
\text { tidak berjamur }\end{array}$ & Putih normal & Normal & Normal & MS \\
\hline ThL & $\begin{array}{c}\text { Normal tidak berlendir dan } \\
\text { tidak berjamur }\end{array}$ & Putih normal & Normal & Normal & MS \\
\hline TmEJ & $\begin{array}{l}\text { Kompak, jika diiris tetap utuh } \\
\text { (tidak mudah rontok) }\end{array}$ & $\begin{array}{l}\text { Putih merata pada } \\
\text { seluruh permukaan }\end{array}$ & $\begin{array}{l}\text { Khas tempe tanpa } \\
\text { adanya bau amoniak }\end{array}$ & - & MS \\
\hline $\mathrm{TmK}$ & $\begin{array}{l}\text { Kompak, jika diiris tetap utuh } \\
\text { (tidak mudah rontok) }\end{array}$ & $\begin{array}{l}\text { Putih merata pada } \\
\text { seluruh permukaan }\end{array}$ & $\begin{array}{l}\text { Khas tempe tanpa } \\
\text { adanya bau amoniak }\end{array}$ & - & MS \\
\hline $\mathrm{TmL}$ & $\begin{array}{l}\text { Kompak, jika diiris tetap utuh } \\
\text { (tidak mudah rontok) }\end{array}$ & $\begin{array}{l}\text { Putih merata pada } \\
\text { seluruh permukaan }\end{array}$ & $\begin{array}{l}\text { Khas tempe tanpa } \\
\text { adanya bau amoniak }\end{array}$ & - & MS \\
\hline
\end{tabular}

\subsection{Identifikasi Formalin pada Sampel Tahu Putih dan Tempe menggunakan Ekstrak Bunga Krisan Merah}

Pengujian organoleptik tidak sepenuhnya dapat diterapkan apabila konsentrasi formalin yang diberikan pada tahu putih dan tempe relatif rendah sehingga keberadaan formalin tidak dapat terdeteksi dengan baik. Untuk memperkuat dan mendukung hasil uji organoleptik sampel tahu putih dan tempe tersebut di atas, dilakukan identifikasi formalin dengan menggunakan ekstrak bunga krisan merah sebagai indikator alami. Hasil identifikasi formalin pada tahu putih dan tempe dilakukan dengan pengamatan secara visual berdasarkan perbandingan perbedaan warna yang dihasilkan, setelah ditambahkan ekstrak bunga krisan merah ke dalam sediaan tahu tempe berformalin (kontrol positif) dan sampel dan dilakukan pengulangan sebanyak 3 (tiga) kali, maka hasil pengamatan dapat dilihat pada Gambar 1 dan Tabel 2.

Berdasarkan hasil pengujian sampel tahu putih dan tempe menggunakan ekstrak bunga krisan merah yang ditunjukkan pada tabel 5, menunjukkan bahwa sampel tahu putih dan tempe yang beredar di ketiga pasar tradisional di kabupaten Ende negatif mengandung formalin. Hal tersebut dapat dilihat dari perubahan warna seperti yang terlihat pada gambar 1. Pada sediaan tahu putih dan tempe berformalin yang digunakan sebagai kontrol positif terjadi perubahan warna yang lebih pekat setelah ditetesi dengan ekstrak bunga krisan merah. Sedangkan pada sampel tahu putih dan tempe warna yang dihasilkan sama dengan warna ekstrak bunga krisan [21].

Keselektifan ekstrak bunga krisan merah dalam menunjukkan keberadaan formalin lewat perubahan warna yang terjadi disebabkan karena terdapat kandungan senyawa golongan flavonoid, yaitu antosianin [22]. Antosianin merupakan pigmen atau zat warna alami yang larut dalam air dan bertanggung jawab memberikan warna merah, ungu, hingga biru pada tanaman (bunga, buah, dan sayuran). Seperti yang dilihat pada gambar 5 dan tabel 1, warna pada sampel tidak mengalami perubahan. Warna yang dihasilkan sama dengan warna ekstrak disebabkan karena kandungan protein pada sampel tahu putih dan tempe yang berperan sebagai kopigmen yang dapat mempengaruhi warna dan stabilitas antosianin. Kopigmentasi yang terjadi akibat adanya protein ini 
mempertahankan warna antosianin dari ekstrak bunga krisan agar tetap stabil dan tidak mengalami perubahan [23].
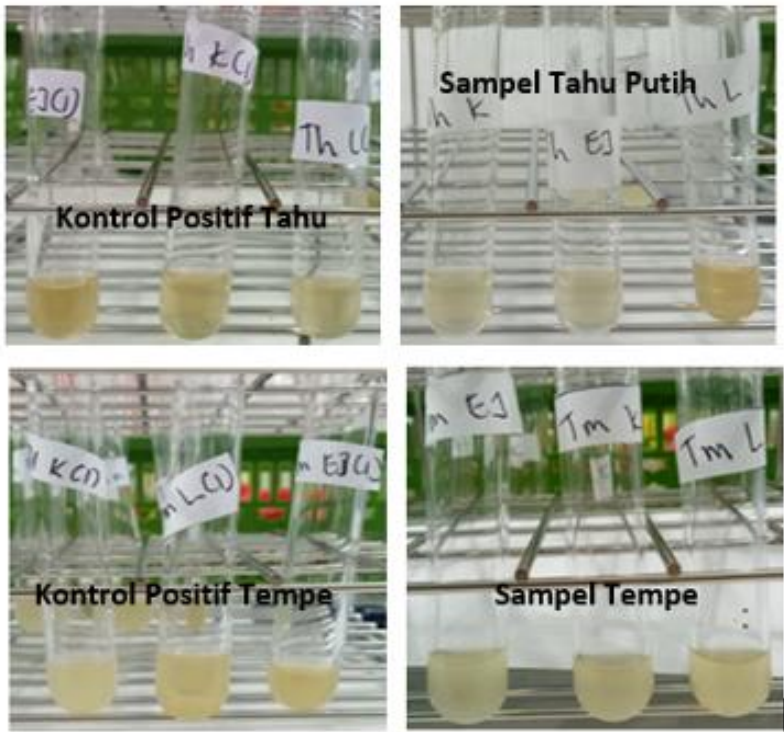

Gambar 1. Hasil Pengamatan Visual Kontrol Positif dan Pengulangan Pengujian Sampel dari Tahu Putih (Th) dan Tempe (Tm) yang Direaksikan dengan Ekstrak Bunga Krisan Merah

Tabel 2. Hasil Pengujian Sampel Tahu Putih dan Tempe menggunakan Ekstrak Bunga Krisan Merah

\begin{tabular}{|c|c|c|c|c|}
\hline \multirow[b]{2}{*}{ Sampel } & \multirow{2}{*}{$\begin{array}{c}\text { Kode } \\
\text { Sampel }\end{array}$} & \multicolumn{3}{|c|}{ Hasil Pengamatan } \\
\hline & & $\begin{array}{c}\text { Pengulangan } \\
\text { I }\end{array}$ & $\begin{array}{c}\text { Pengulangan } \\
\text { II }\end{array}$ & $\begin{array}{c}\text { Pengulangan } \\
\text { III }\end{array}$ \\
\hline \multirow{3}{*}{$\begin{array}{l}\text { Tahu } \\
\text { Putih }\end{array}$} & ThEJ & - & - & - \\
\hline & ThK & - & - & - \\
\hline & ThL & - & - & - \\
\hline \multirow{3}{*}{ Tempe } & TmEJ & - & - & - \\
\hline & $\mathrm{TmK}$ & - & - & - \\
\hline & $\mathrm{TmL}$ & - & - & - \\
\hline
\end{tabular}

Pada sediaan tahu tempe berformalin yang digunakan sebagai kontrol positif, protein pada tahu dan tempe akan berikatan dengan formalin yang memiliki unsur aldehid. Aldehid pada formalin akan mudah bereaksi dengan protein. Pengikatan protein oleh formalin menyebabkan protein memiliki struktur senyawa metilen. Bakteri pembusuk yang terdapat di dalam tahu dan tempe tidak dapat memanfaatkan protein tersebut, karena protein dengan struktur metilen tidak dapat diuraikan oleh bakteri sehingga tahu putih dan tempe menjadi awet dan tahan lama [24,25].

Formalin memiliki sifat asam kuat karena mengandung asam formiat yang merupakan hasil dari oksidasi formaldehida. Sifat asam kuat pada formalin ini akan memudahkan antosianin dalam mendeteksi keberadaan formalin pada tahu putih dan tempe. Antosianin akan bereaksi dengan asam kuat, dan warna yang dihasilkan pun akan berubah, yaitu menjadi lebih pekat karena berikatan dengan asam. Warna yang ditimbulkan tergantung dari jenis antosianin dari ekstrak bunga krisan merah yang dihasilkan [26]. Ada dan tidaknya perubahan warna yang dihasilkan menunjukkan bahwa ekstrak bunga krisan merah dapat dijadikan sebagai indikator alami dalam mengidentifikasi keberadaan formalin.

\section{Kesimpulan}

Berdasarkan hasil dan pembahasan, maka kesimpulan dari penelitian ini adalah ekstrak bunga krisan merah dapat digunakan sebagai indikator alami untuk mengetahui keberadaan formalin dalam bahan pangan, khususnya dalam tahu putih dan tempe. Selain itu juga, tahu putih dan tempe yang beredar di pasar tradisional kota Ende layak untuk dijual dan dikonsumsi oleh masyarakat karena negatif mengandung formalin. 


\section{Ucapan Terima Kasih}

Ucapan terima kasih peneliti sampaikan kepada Laboratorium LOKA Pengawas Obat dan Makanan (POM) Kabupaten Ende, dan Lembaga Penelitian dan Pengabdian kepada Masyarakat Universitas Flores yang telah mendukung dan memfasilitasi pelaksanaan penelitian.

\section{Daftar Pustaka}

[1] Sumiati, "Purple cabbage extracts (Brasicca oleracea L.) as tofu's formalin indicators," Integrated Lab Journal, vol. 7(1), hal. 44-55, 2019.

[2] M. U. Aziza, M. Z. Rahfiludin, dan D. R. Pangestuti, "Perbedaan kadar formalin pada tahu putih di tingkat produsen dan pedagang kota Semarang tahun 2016," Jurnal Kesehatan Masyarakat, vol. 5(1), hal. 291-300, 2017.

[3] Badan Pusat Statistik, Pengeluaran untuk Konsumsi Penduduk Indonesia Per Provinsi Berdasarkan Hasil Susenas Maret 2018, Jakarta: BPS-RI, 2018.

[4] Syarfaini dan M. Rusmin, "Analisis kandungan formalin pada tahu di pasar tradisional kota Makassar tahun 2014," Al-Sihah: Public Health Science Journal, vol. 6(2), hal. 1-11, 2014.

[5] Z. Berlian, E. R. Pane, dan S. Hartati, "Efektivitas kunyit (Curcuma domestica) sebagai pereduksi formalin pada tahu," Jurnal SainHealth, vol. 1(1), hal. 1-14, 2017.

[6] Y. A. Purwanto dan Weliana, "Kualitas tempe kedelai pada berbagai suhu penyimpanan," Journal of Agro-based Industry, vol. 35(2), hal. 106-112, 2018.

[7] A. Yuliantini dan W. Rahmawati, "Analisis kualitatif boraks dengan indikator alami ekstrak bunga telang (Clitoria ternatea L.)," Sainstech Farma: Jurnal Ilmu Kefarmasian, vol. 12(1), hal 13-16, 2019.

[8] Wirhanuddin dan A. Majid, "Analisis boraks dan formalin pada produk jajanan tahu di lingkungan keguruan dan ilmu pendidikan Universitas Mulawarman, kampus gunung kelua Samarinda," Prosiding Semnas Kimia dan Pendidikan Kimia, Universitas Mulawarman, hal. 14-16, 2017.

[9] Y. Paratmanitya dan V. Aprillia, "Kandungan bahan tambahan pangan berbahaya pada makanan jajanan anak sekolah dasar di kabupaten Bantul," Jurnal Gizi dan Dietetik Indonesia, vol. 4(1), hal. 49-55, 2016.

[10] S. Kholifah dan D. Utomo, "Uji boraks dan formalin pada jajanan di sekitar Universitas Yudharta Pasuruan,” Jurnal Teknologi Pangan, vol. 9(1), hal. 10-19, 2018.

[11] A. P. Adisasmita, S. Yuliawati, dan R. Hestiningsih, "Survei keberadaan formalin pada produk perikanan laut segar yang dijual di pasar tradisional kota Semarang," Jurnal Kesehatan Masyarakat, vol. 3(3), hal. 109-119, 2015.

[12] N. Yulisa, E. Asni, dan M. Azrin, "Uji formalin pada ikan asin gurami di pasar tradisional Pekanbaru," Jom FK, vol. 1(2), hal. 1-12, 2014.

[13] N. Rochyani, M. R. Akbar, dan Y. Randi, "Pembuatan media uji formalin dan boraks menggunakan zat antosianin dengan pelarut etanol 70\%," Jurnal Redoks, vol. 2(1), hal. 28-35, 2017.

[14] S. R. Dewi, "Identifikasi formalin pada makanan menggunakan ekstrak kulit buah naga," Jurnal Nasional Ilmu Kesehatan (JNIK), vol. 2(1), hal. 45-51, 2019.

[15] Riniati, A. Sularasa, dan A. D. Febrianto, "Ekstraksi kembang sepatu (Hibiscus Rosa Sinensis L.) menggunakan pelarut metanol dengan metode sokletasi untuk indikator titrasi asam basa," Indonesian Journal of Chemical Analysis, vol. 2(1), hal. 34-40, 2019.

[16] C. H. Park, S. C. Chae, S. Y. Park, J. K. Kim, Y. J. Kim, S. O. Chung, M. V. Arasu, N. A. Al-Dhabi, dan S. U. Park, "Anthocyanin and carotenoid contents in different cultivars of chrysanthemum (Dendranthema grandiflorum Ramat.) flower,” Molecules, vol. 20, pp. 11090 - 11102, 2015.

[17] M. Priska, N. Peni, L. Carvallo, dan Y. D. Ngapa, "Review: antosianin dan pemanfaatannya," Cakra Kimia (Indonesian E-Journal of Applied Chemistry), vol. 6(2), hal. 79 - 97, 2018.

[18] Anonymous, Standar Nasional Indonesia SNI 01-3142-1998, Tahu, Jakarta: Badan Standardisasi Nasional, 1998. 
[19] Anonymous, Standar Nasional Indonesia SNI 3144-2015, Tempe. Jakarta: Badan Standardisasi Nasional, 2015.

[20] Nuhman dan A. E. Wilujeng, "Pemanfaatan ekstrak antosianin dari bahan alam untuk identifikasi formalin pada tahu putih," Jurnal Sains, vol. 7(14), hal. 8-15, 2017.

[21] A. E. Novitasari dan Z. A. Barik, "Pemanfaatan ekstrak antosianin dari bunga kembang sepatu (Hibiscus-rosa sinensis L.) sebagai indikator untuk identifikasi boraks," Jurnal Sains, vol. 8(16): 8 - 15, 2018.

[22] A. Amanda dan I. Kurniaty, "Pengaruh waktu maserasi terhadap rendemen zat antosianin pewarna alami minuman jelly dari terong ungu," Seminar Nasional Sains dan Teknologi 2017, Fakultas Teknik Universitas Muhammadiyah Jakarta, 2017.

[23] I. Sangadji, M. Rijal, dan Y. A. Kusuma, "Kandungan antosianin di dalam mahkota bunga beberapa tanaman hias," Jurnal Biology Science \& Education, vol. 6(2), hal. 118-128, 2017.

[24] A. Yuliantini dan W. Rahmawati, "Deteksi formalin dalam makanan dengan indikator alami dari ekstrak bunga telang (Clitoria ternater L.)," Journal of Pharmacopolium, vol. 1(3), hal. 107-113, 2018.

[25] S. Purawisastra dan E. Sahara, "Penyerapan formalin oleh beberapa jenis bahan makanan serta penghilangannya melalui perendaman dalam air panas," PGM, vol. 34(1), hal. 63-74, 2011.

[26] N. Rochyani, "Comparison analysis of anthocyanin subtances in various plants for testing media of formalin and borax content in food," E3S Web of Conferences, vol. 68, pp. 1-9, 2018. 